
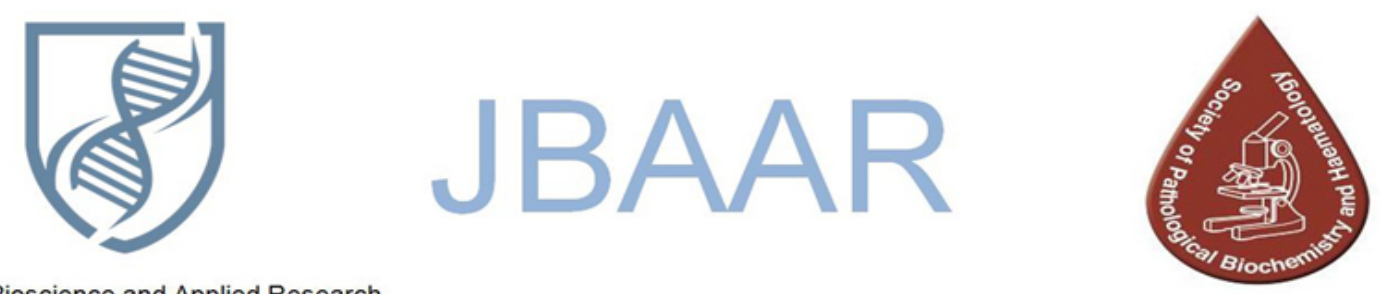

Journal of Bioscience and Applied Research

WWW.JBAAR.ORG

\title{
Ameliorative effect of Cymbopogon citratus extract on cisplatin-induced genotoxicity in human leukocytes
}

\author{
Islam M. El-Garawani \\ Department of Zoology, Faculty of Science, Menofia University, Menofia, Egypt. \\ Email:dr.garawani@yahoo.com
}

\begin{abstract}
Cisplatin (Cis) as anticancer drug has many side effects and reducing the levels of plasma antioxidants and generating non-selective targeting of cancerous cells. In this work, the free radicals in normal cells (Weijl et al., 1998 and Yoshida antigenotoxic potential of lemon grass (Cymbopogon et al., 2003). It also induces chromosomal aberrations in citratus) leaves aqueous extract (CC) against the cisplatin- mammalian cells and human peripheral blood lymphocytes induced genotoxicity in human peripheral leukocytes was in vitro (Osanto et al., 1991; Nefic and Ibrulj, 1999 and investigated in vitro. Firstly, the antioxidant activity of Khabour et al., 2014), and sister-chromatid exchanges in plant extract was investigated by DPPH method which human lymphocytes in vitro (Bradley et al., 1979 and proved a good antioxidant potential of CC extract. CC Khabour et al., 2014). It increases the micronuclei enhanced the proliferation and increased cell count when frequency in cisplatin -treated human lymphocytes in vitro compared to the control and Cis-treated groups. (Gebel et al., 1997).

Furthermore, the expression of nuclear protein $\mathrm{Ki}-67$ as a A considerable attention is currently focuses on preventing marker of cell proliferation was tested genotoxic effects of anticancer drugs by using the immunocytochemically and the results supported the antioxidants of natural origin. Cymbopogon citratus which ameliorative effect of CC against the genotoxic effect of is belonging to Poaceae family is a tall aromatic grass of Cis. The nuclear dual acridine orange/ethidium bromide approximately $1.5 \mathrm{~m} \mathrm{high}$. It is a monocotyledonous fluorescent staining of cells showed the distinct perennial grass which has slender sharp edged leaves. CC morphological features of apoptosis and cell death among has no toxic effects in Brazilian traditional folk medicine Cis-treated groups. The reduction of total genomic DNA (Souza-Formigoni et al., 1986). Its leaves tea made is used fragmentation on agarose gel was noted among CC-treated in Brazil as antispasmodic, analgesic, anti-inflammatory, groups when compared to Cis-treated groups.

Keywords: Cisplatin, Cymbopogon citratus, genotoxicity, leukocytes and proliferation in vitro.

\section{Introduction}

Cisplatin (cis-diamminedichloroplatinum), is one of many anti-cancer drugs that causing DNA damage. Although cisplatin is a powerful chemotherapeutic drug in the solid cancers treatment, it also has great side effects such as antipyretic, diuretic and sedative (Carlini et al., 1986). Lemon grass leaves aqueous extract exert cytoprotective and antioxidant properties (Lee et al., 2008; Figueirinha et al., 2010 and Tiwari et al. 2010). It is also reported that lemon grass inhibited human lymphocytes damage induced by mitomycin-C (Meevatee et al., 1993). Hepatic oxidative stress and toxicity induced by cisplatin in albino rats can be alleviated by lemon grass aqueous extract (Arhoghro et al., 2014).
\end{abstract}


The present study was conducted to investigate the potent ameliorative effect of lemon grass aqueous leaves extract against the possible genotoxic effect of cisplatin on human peripheral leukocytes in vitro.

\section{Materials and Methods}

\section{A. Chemicals}

I. Cis - diamminedichloroplatinum, Cisplatin, (Unistin, EIMC, Egypt).

II. Ascorbic acid (vitamin C), Sigma pharmaceuticals (assay: 99.1\%), was prepared fresh in methanol as a standard stock solution.

III. 2,2-diphenyl-1-picrylhydrazyl free radicals (DPPH), Sigma pharmaceuticals, was freshly prepared as a $0.3 \mathrm{mM}$ stock solution in methanol.

IV. Medicinal plant: lemon grass (Cymbopogon citratus) was obtained freshly from Applied Research Center of Medicinal Plant (ARCMP), Kafr El Gabal, Giza, Egypt.

All chemicals used in this work were of high analytical grade.

\section{B. Methods}

Preparation of Cymbopogon citratus aqueous extracts Fresh leaves were collected and minced into fine pieces. $200 \mathrm{~g}$ of leaves was extracted with $40 \mathrm{X}$ (w/v) of hot distilled water at $55^{\circ} \mathrm{C}$ for 6 hours. The extract was then filtered using Whatman filter paper (No. 1). The filtrate was lyophilized by a freeze-dryer (Sniffers scientific, Holland), and then it was stored at $-20^{\circ} \mathrm{C}$ until use (Kumazawa et al., 2002).

\section{Determination of free radical scavenging potential of Cymbopogon citrates extract by DPPH assay}

The 2, 2-diphenyl-1-picrylhydrazyl free radical scavenging assay was done to determine the antioxidant activity of the Cymbopogon citratus leaves aqueous extract. The changes in color from violet to yellow which caused by the scavenging reaction were evaluated colorimetrically at 517 nm using a UV-VIS spectrophotometer (Hewlett Packard, USA) (Blois, 1958). The \% antioxidant activities (AA \%) was calculated according to the following equation:

$$
A A \%=100-\left[100 \times\left(A b s_{\text {sample }}-A b s_{\text {blank }}\right) / A b s_{\text {control }}\right]
$$

The test was carried out three times independently.

\section{Study design}

Human peripheral blood cultures were divided into nine groups as follow:

Normal (untreated),

Cisplatin $(5 \mu \mathrm{g} / \mathrm{ml})$,

Cisplatin $(10 \mu \mathrm{g} / \mathrm{ml})$,
Cymbopogon citratus $(5 \mu \mathrm{g} / \mathrm{ml})$,

Cymbopogon citratus $(10 \mu \mathrm{g} / \mathrm{ml})$,

Cisplatin $(5 \mu \mathrm{g} / \mathrm{ml})+$ Cymbopogon citratus $(5 \mu \mathrm{g} / \mathrm{ml})$, Cisplatin $(5 \mu \mathrm{g} / \mathrm{ml})+$ Cymbopogon citratus $(10 \mu \mathrm{g} / \mathrm{ml})$, Cisplatin $(10 \mu \mathrm{g} / \mathrm{ml})+$ Cymbopogon citratus $(5 \mu \mathrm{g} / \mathrm{ml})$ and Cisplatin $(10 \mu \mathrm{g} / \mathrm{ml})+$ Cymbopogon citratus $(10 \mu \mathrm{g} / \mathrm{ml})$.

Each group was processed as three replicates.

\section{Cell culturing and treatments}

Peripheral blood was collected from normal healthy nonsmoker male volunteer under sterile conditions and EDTAanticoagulant. One milliliter of whole peripheral blood was cultured in 5ml RPMI-1640 supplemented with $15 \%$ heatinactivated fetal bovine serum, penicillin $(100 \mathrm{U} / \mathrm{ml})$ streptomycin $\quad(100 \mathrm{~g} / \mathrm{ml}) \quad$ and $\quad(10 \mathrm{~g} / \mathrm{ml})$ phytohemagglutinin, then the tubes were kept at $37^{\circ} \mathrm{C}$. All components were (GIBCO-BRL). Treatments were administered after $48 \mathrm{~h}$ of incubation, then left to complete $72 \mathrm{~h}$ before harvest. Simultaneous treatment was carried out among the groups of cisplatin and Cymbopogon citratus combination.

\section{Peripheral leukocytes isolation}

Leukocytes were isolated from treated and control cultured blood by incubation with $8 \mathrm{ml}$ erythrocyte lysing buffer $\left(0.015 \mathrm{M} \mathrm{NH} \mathrm{N}_{4} \mathrm{C} 1,1 \mathrm{mM} \mathrm{NaHCO} 3,0.1 \mathrm{mM}\right.$ EDTA). Then, they were centrifuged for 5 minutes at $1000 \mathrm{rpm}$ using cooling centrifuge (Sigma 3K 30, Germany). These steps were repeated until a white pellet appeared (Punareewattana et al., 2001).

\section{Cell viability and count assay}

The viability test was carried out for the harvested cells according to (Darzynkiewiez et al., 1994). Briefly, 10 $\mu$ l of $0.4 \%$ trypan blue stain were added to $10 \mu \mathrm{l}$ of cell suspension and the total of 500 cells was recorded for viable cells against dead cells. The total count per $1 \mathrm{ml}$ was also evaluated using haemocytometer under a light microscope (Olympus, Japan).

The viability percentage was calculated as follow:

$\%$ Viability $=$ (Number of viable cells/ Number of viable and non-viable cells) x 100 .

\section{Evaluation of cell cycle arrest by Ki-67 expression}

The nuclear antigen Ki-67, which expressed during most phases of the cell cycle, a marker of proliferating cells, was detected using monoclonal antibodies Ki-67. The functional capacity of leukocytes was evaluated by the amount of visualized Ki-67 stained positive cells.

For immunocytochemical localization of Ki-67, cells were stained using avidin-biotin complex immunoperoxidase 
technique (Cordone et al., 1992). The mouse anti human Ki-67 monoclonal antibody was used for the detection of nuclear Ki-67 (DakoCytomation, Glostrup, Denmark). Counterstaining was performed using Mayer's hematoxylin. The mean percentage of Ki-67 positively stained cells under $\times 100$ magnifications was calculated using light microscope (Olympus, Japan) and representative images were captured. Scoring of Ki-67 expression was performed as negative (blue nuclei) and positive (brown stained nuclei) of 500 cells per sample.

Dual acridine orange/ethidium bromide fluorescent staining

Ethidium bromide/acridine orange staining was carried out to detect the morphological evidence of apoptosis and viability of treated and control groups, $10 \mu \mathrm{l}$ of cells were incubated for 1 minutes with $5 \mu \mathrm{l}(10 \mu \mathrm{g} / \mathrm{ml})$ of a solution of acridine orange/ethidium bromide $1: 1$ ratio of (100 $\mu \mathrm{g} / \mathrm{ml}$ ) in PBS. Stained cells were visualized under (Olympus fluorescence microscopes, Japan) immediately and the images were digitally photographed. The apoptotic cells, with their shrunken, nuclear fragmentation, bright orange fluorescent and condensed chromatin were scored and the percentage of apoptotic cells were calculated, while the viable normal cells appeared green in color.

\section{Detection of DNA fragmentation by agarose gel electrophoresis}

DNA extraction and detection of fragmentation were done according to "salting out extraction method" of Aljanabi and Martinez (1997) with some modifications by Hassab El-Nabi and Elhassaneen (2008). Harvested cells were lysed in $300 \mu \mathrm{l}$ lysing buffer $(50 \mathrm{mM} \mathrm{NaCl}, 1 \mathrm{mM} \mathrm{Na}$ EDTA, $0.5 \%$ sodium dodecyl sulfate, $\mathrm{pH} 8.3$ ) overnight at $37^{\circ} \mathrm{C}$ then; $100 \mu \mathrm{l}$ of $4 \mathrm{M} \mathrm{NaCl}$ was added to the samples. Centrifuge the mixture at $10,000 \mathrm{rpm}$ for 10 minutes. The supernatant was transferred to a new tube then DNA was precipitated by $1 \mathrm{ml}$ cold isopropanol by centrifugation for $10 \mathrm{~min}$ at $12.000 \mathrm{rpm}$. Wash the pellets with $1 \mathrm{ml} 70 \%$ ethyl alcohol twice. Resuspend the pellets in TE buffer (10 mM Tris, 1mM EDTA, $\mathrm{pH} 8$ ). Incubate for 30 - 60 minutes with loading mixture $(0.1 \%$ RNase + loading buffer), and then samples were loaded directly into agarose gel wells. All centrifugation steps were done at $4^{\circ} \mathrm{C}$ using (Sigma $3 \mathrm{~K}$ 30, Germany). The extracted DNA samples were estimated spectrophotometrically for purity at optical density (OD) 260/280 using (Hewlett Packard 8453, USA) spectrophotometer (Surzycki, 2000).

Gels were prepared using $1.8 \%$ normal melting electrophoretic grade agarose in $1 \mathrm{X}$ Tris borate EDTA buffer and electrophoresed for $1 \mathrm{~h}$ at 50 volts. The fragmented DNA appeared and located throughout the lanes against thirteen bands of DNA marker (100-3000 bp). The intensities of fragmented DNA molecules were measured by (Biogene software, France) as a maximum optical density values.

\section{Statistical analysis}

Results were expressed as the Mean \pm Standard Deviation $(\mathrm{M} \pm \mathrm{SD})$. Student's $t$-test, for normally distributed data (McClave and Dietrich, 1991), was used to calculate the significance of differences observed between mean values of treated and control groups at a level of significance of $(P$ $<0.05)$.

\section{Results}

Determination of free radical scavenging activity of the extract by 2, 2-diphenyl-1-picrylhydrazyl assay (DPPH) The results revealed the presence of an increase in the percentage of antioxidant activities of $\mathrm{CC}$ extract in a concentration-dependent manner which reached about $100 \%$ at a concentration of $89.86 \mu \mathrm{g} / \mathrm{ml}$ to be in parallel with ascorbic acid value at $97.14 \mu \mathrm{g} / \mathrm{ml}$ (Figure 1).

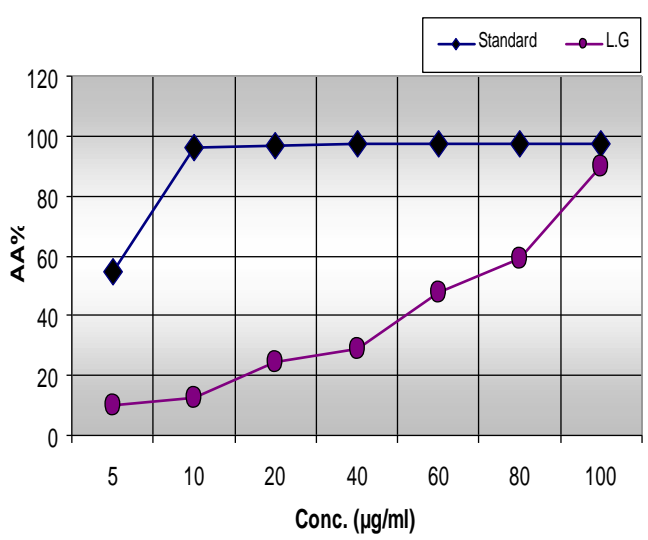

Figure (1): Free radical scavenging activity of CC (LG) extract using a stable DPPH radical against vitamin C (standard).

\section{Cell viability and count}

The standard trypan blue viability test revealed that all tested groups have about $95 \%$ viable cells after 48 hours of culturing before treatments administration.

Cells count was carried out after cells harvest at the end of the experiment (48 hours of culturing then 24 hours of treatment administration) and the results were expressed in (Table 1) which shows the decrease in proliferation capacity due to Cis treatments in concentration dependent manner and the modulation of this inhibition by $\mathrm{CC}$ $(10 \mu \mathrm{g} / \mathrm{ml})$ simultaneous treatments. While low dose of CC $(5 \mu \mathrm{g} / \mathrm{ml})$ fail to ameliorate that inhibition. In addition, the 
enhancement of proliferation was countered among the CC groups when compared to the untreated groups.

\section{Evaluation of cell cycle arrest by Ki-67 expression}

The nuclear antigen Ki-67 expression which evaluated as a mean percentage of positive stained (brown) cells counting revealed the antiproliferative effect of $C$ is which was noted by the decrease of $\mathrm{Ki}-67$ expression with respect to untreated groups shifting cells towards G0 resting state. Moreover, the successful ameliorative potential of simultaneous CC $(10 \mu \mathrm{g} / \mathrm{ml})$ treatment against Cis $(5$ and $10 \mu \mathrm{g} / \mathrm{ml})$ toxicity. While low dose of $\mathrm{CC}(5 \mu \mathrm{g} / \mathrm{ml})$ fail to ameliorate the Cis antiproliferative effect. Additionally, $\mathrm{CC}$ treatment alone enhanced the proliferation capacity of cells which obviously noted by the increase of $\mathrm{Ki}-67$ expression when compared to untreated and Cis-treated groups (Table 1).

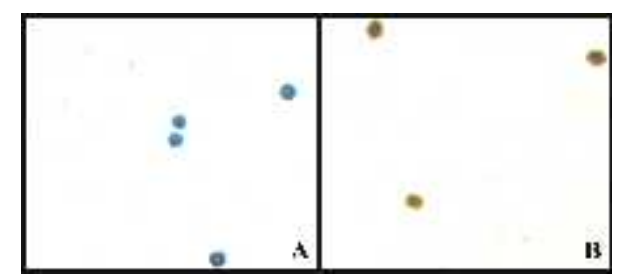

Figure (2): represents the Ki-67 expression where A: non expressed (-ve, blue) cells and B: expressed (+ve, brown) cells (1000X).

\section{Detection of morphological changes by dual-fluorescent assay}

Cytological study using ethidium bromide/acridine orange staining method by which early-stage of apoptosis appears granular yellow-green while the late-stage or necrotic cells are marked by orange-red fluorescence (Figure 3 ). The results showed typical apoptotic morphology with condensed nuclei, changes in staining intensity with orange to red fluorescence among the treatment groups supporting the successful ameliorative properties of $\mathrm{CC}$ against $\mathrm{Cis}$ low dose $(5 \mu \mathrm{g} / \mathrm{ml})$. While $\mathrm{CC}$ fail to ameliorate the toxic effect of Cis high dose $(10 \mu \mathrm{g} / \mathrm{ml})$ when compared to Cistreated groups. Normal untreated group has no significant apoptosis and only green fluorescent nuclei were observed (Table 1).
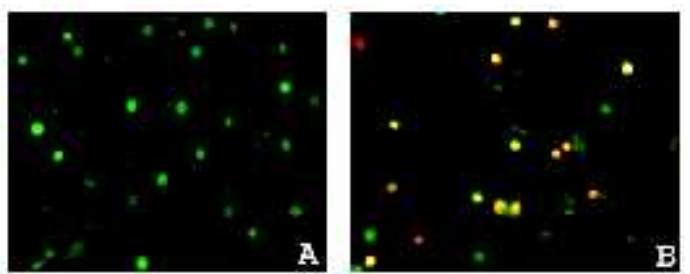

Figure (3): represents the morphological changes which evaluated by dual ethidium bromide/acridine orange fluorescent staining method. Where A: control (normal) cells and B: apoptotic cells (400X).
Detection of total genomic DNA fragmentation

The obtained results (Figure 4) revealed the powerful protection of $\mathrm{CC}$ extract against the total genomic DNA damage which has been induced by Cis treatment high dose more than Cis low dose. The DNA fragmentation was obviously countered as optical densities of fragmented DNA molecules at Cis low and high dose groups as $(53.2 \pm 3.74$ and $77.1 \pm 2.5)$ respectively, which were ameliorated by $\mathrm{CC}$ high dose treatment more than that of $\mathrm{CC}$ low dose. While no fragmentation can be observed among other groups when compared with untreated groups (Table 1).

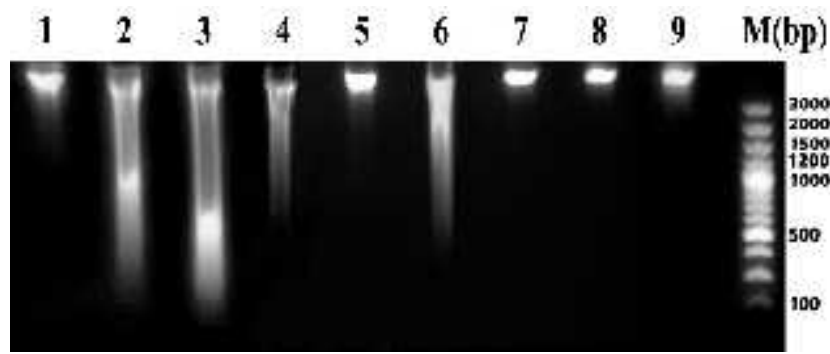

Figure (4): representative digital photo of total genomic DNA of harvested cells showing the ameliorative effect of CC against the damage induced by Cis. Where, 1: Normal (untreated) leukocytes, 2: Cisplatin $(5 \mu \mathrm{g} / \mathrm{ml}), 3$ : Cisplatin $(10 \mu \mathrm{g} / \mathrm{ml}), 4$ : Cisplatin (5 $\mu \mathrm{g} / \mathrm{ml})+$ Cymbopogon citratus $(5 \mu \mathrm{g} / \mathrm{ml}), 5$ : Cisplatin $(5 \mu \mathrm{g} / \mathrm{ml})+$ Cymbopogon citratus $(10 \mu \mathrm{g} / \mathrm{ml}), 6$ : Cisplatin $(10 \mu \mathrm{g} / \mathrm{ml})+$ Cymbopogon citratus $(5 \mu \mathrm{g} / \mathrm{ml}), 7$ : Cisplatin $(10 \mu \mathrm{g} / \mathrm{ml})+$ Cymbopogon citratus $(10 \mu \mathrm{g} / \mathrm{ml})$, 8: Cymbopogon citratus $(5 \mu \mathrm{g} / \mathrm{ml}), 9:$ Cymbopogon citratus $(10 \mu \mathrm{g} / \mathrm{ml})$ and M: $100-3000 \mathrm{bp}$ marker.

\section{Discussion}

Although cisplatin is a powerful and widely used anti neoplastic drug in adults and many pediatric cases, its clinical use is highly limited due to its remarkable side effects. The major suggested mechanism by which cisplatin exerts its genotoxic effect is by its ability to induce oxidative stress inside cells (Khabour et al., 2014) and free radical generation (Yoshida et al., 2003). The cytotoxicity of the drug is also thought to be due to its ability to bind DNA to form cisplatin-DNA adducts, beside that, the intracellular accumulation of cisplatin, impaired DNArepair processes, and decreased levels of cisplatininactivating factors, such as glutathione and metallothioneins (Perez, 1998; Zhang et al., 2001; Rajewsky and Müller, 2002). Due to the non-selectivity of cytotoxic drugs in targeting normal and cancerous cells (Thomas et al., 2000), the alternative cancer therapy is valuable and has to be established.

Recently, the modulation of toxic effect by natural origin extract has been paid a great attention. Plants have the 
ability to synthesize aromatic substances such as evaluated by cell count and Ki-67 down expression. While polyphenolic compounds, mainly flavonoids and phenolic CC treatment enhanced cell proliferation and modulated acids, which have potent antioxidant activities due to their Cis toxic effects, which may be due to the antioxidant hydrogen-donating and metal-chelating capacities. These activities of CC leaves extract (Kanatt et al., 2014).

flavonoids and polyphenolics have been proved to possess On the other hand, the results of total genomic DNA the ability to scavenge several oxidizing species such as fragmentation and morphological changes by dualhydroxyl radicals (Shimoi et al., 1996, 2000; Benavente- fluorescent assay supported the previous results as the Garc'ia et al., 2002). In this work, the DPPH assay results effective CC protection, specially high dose $(10 \mu \mathrm{g} / \mathrm{ml})$, proved the antioxidant activities of CC leaves aqueous against the genotoxic effect of Cis (De et al., 2015) and extract (Kanatt et al., 2014) which may be due to its enhancement of cells proliferation which also an evidence contents of phenolic acids, flavonoids and tannins of the antioxidant potential of CC extract.

(Olorunnisola et al. 2014).

The nuclear antigen Ki-67 is a protein detected in G1, S, Acknowledgements

G2 and M phases of the cell cycle, but not in G0 (Diop et The author thanks the volunteer for blood samples.

al., 2005). It is used to recognize proliferating cells while it is absent in resting cells (Gerdes et al., 1983). In this study, Funding

the results of cell count and Ki-67 nuclear expression This research did not receive any funding. revealed that Cis caused cell cycle arrest which has been

Table (1): shows the $\%$ of cells count variation with respect to control, \% of morphological evidence of apoptosis evaluated by acridine orange/ ethidium bromide dual fluorescent staining method, the mean optical densities of fragmented DNA on agarose gel and \% of Ki-67 +ve cells for treated and untreated groups.

\begin{tabular}{|c|c|c|c|c|c|c|c|c|c|}
\hline & \multirow[b]{2}{*}{ Control } & \multicolumn{8}{|c|}{ Treatments $(\mu \mathrm{g} / \mathrm{ml})$} \\
\hline & & 5 Cis & 10 Cis & $5 \mathrm{CC}$ & $10 \mathrm{CC}$ & $\begin{array}{c}5 \mathrm{Cis}+ \\
5 \mathrm{CC}\end{array}$ & $\begin{array}{c}5 \mathrm{Cis}+ \\
10 \mathrm{CC}\end{array}$ & $\begin{array}{c}\text { 10Cis }+ \\
5 \mathrm{CC}\end{array}$ & $\begin{array}{c}10 \mathrm{Cis}+ \\
10 \mathrm{CC}\end{array}$ \\
\hline $\begin{array}{l}\% \text { cells } \\
\text { count }\end{array}$ & $-\cdots--\cdot$ & $-20.6 \pm 0.47$ & $-32.2 \pm 0.25$ & $+45.6 \pm 0.60$ & $+47.5 \pm 1.41$ & $+30.2 \pm 0.96$ & $+44.6 \pm 1.40$ & $-58.3 \pm 1.38$ & $-15.9 \pm 1.37$ \\
\hline $\begin{array}{l}\% \text { Ki-67 } \\
+ \text { +ve cells }\end{array}$ & $72.3 \pm 2.52$ & $27.7 \pm 1.35$ & $21.7 \pm 1.10$ & $82.7 \pm 1.51$ & $85.0 \pm 1.25$ & $63.3 \pm 2.40$ & $83.8 \pm 1.37$ & $21.8 \pm 0.61$ & $35.0 \pm 1.15$ \\
\hline $\begin{array}{l}\text { \% Apoptotic } \\
\text { cells }\end{array}$ & $4.1 \pm 1.0$ & $31.0 \pm 0.15^{\mathrm{a}}$ & $41.1 \pm 0.96^{\mathrm{a}}$ & $5.4 \pm 0.26$ & $14.7 \pm 0.74^{\mathrm{a}}$ & $5.6 \pm 0.35$ & $23.7 \pm 0.89^{\mathrm{a}}$ & $32.9 \pm 0.95^{\mathrm{a}}$ & $42.1 \pm 2.61^{\mathrm{a}}$ \\
\hline $\begin{array}{c}\text { Fragmented } \\
\text { DNA }\end{array}$ & $4.5 \pm 1.43$ & $53.2 \pm 3.74^{\mathrm{a}}$ & $77.1 \pm 2.56^{\mathrm{a}}$ & $5.3 \pm 1.91$ & $4.0 \pm 1.99$ & $30.6 \pm 3.43^{\mathrm{a}}$ & $5.9 \pm 1.65$ & $42.9 \pm 2.70^{\mathrm{a}}$ & $7.5 \pm 1.45$ \\
\hline
\end{tabular}

${ }^{\mathrm{a}} p<0.05$ : significance with respect to the control group for fluorescent apoptotic cells percentages and DNA fragmentation optical densities. Cis: Cisplatin and CC: Cymbopogon citratus

\section{References}

Benavente-Garc'ía O, Castillo J, Lorente $\mathrm{J}$ and

Aljanabi SM and Martinez I (1997). Universal and Alzaraz M (2002). Radioprotective effect in vivo of rapid salt-extraction of high quality genomic DNA for PCR- phenolic extracted from Olea europea L. leaves against Xbased techniques. Nuc. Acids Res. 25: 4692-4693.

Arhoghro EM, Ikeh C and Prohp TP (2014). ray-induced chromosomal damage: comparative study versus several flavonoids and sulfur-containing compounds. J Med Food 5 (3): 125-135.

Cymbopogon citrates aqueous extract alleviates cisplatininduced hepatic oxidative stress and toxicity in albino rats. Int J Curr Microbiol Appl Sci. 3(4): 586-604.

Blois MS (1958). Antioxidant determination by the use of a stable free radical. Nature 191: 1199-1200. 
Bradley MO, Hsu IC and Harris CC (1979). Relationships between sister-chromatid exchange and mutagenicity, toxicity and DNA damage. Nature 282: 318 320 .

Carlini EA, Contar JDP, Silva-Filho AR, SilveiraFilho NG, Frochtengarten ML and Bueno OF (1986) Pharmacology of lemongrass (Cymbopogon citratus Stapf) I. Effects of teas prepared from the leaves on laboratory animals. J Ethnopharmacol. 17(1): 37-64.

Darzynkiewiez Z, Li X and Gong J (1994). Assay for cell viability: discrimination of cells dying by apoptosis. Methods Cell Biol 41: 15-38. Cordone I, Matutes E, Catovsky D (1992).
Monoclonal antibody Ki-67 identifies B and T cells in cycle in chronic lymphocytic leukemia:Correlation with disease activity. Leukemia 6: 902.

De P, Mukhopadhyay MJ and Chakravarty A (2015). Lemongrass - an anticlastogenic agent against arsenic. The Nucleus 58 (2): 125-129.

Diop S, Letestu R, Orsolani D, Leboeuf Y, Le Tutour P, Thiam D, Diakhate L and Valensi F (2005) Expression of proliferation marker $\mathrm{Ki} 67$ in chronic lymphocytic leukemia. Dakar Med J 50 (2): 65-68.

Figueirinha A, Cruz MT, Francisco V, Lopes MC and Batista MT (2010). Anti-inflammatory activity of Cymbopogon citratus leaf infusion in lipopolysaccharidestimulated dendritic cells: contribution of the polyphenols. J Med Food 13(3): 681-90.

Gebel T, Lantzsch H, Pleow K and Dunkelberg H (1997).Genotoxicity of platinum and palladium compounds in human and bacterial cells. Mut Res 389: 183-190.

Gerdes J, Schwab U, Lemke H and Stein H (1983). Production of a mouse monoclonal antibody reactive with a human nuclear antigen associate with proliferation. Int $\mathrm{J}$ Cancer 31: 13-20.

Hassab El-Nabi SE and Elhassaneen YA (2008). Detection of DNA damage, molecular apoptosis and Longstreth J, Snodgrass HL, Gogal JRR, Prater RM and production of home-made ladder by using simple technique. Holladay SD (2001). Topical permethrin exposure inhibits Biotech. 7 (3): 514- 522.

Kanatt SR, Chawla SP and Sharma A (2014). Antioxidant and radio-protective activities of lemon grass and star anise extracts. Food Biosc. 6: 24-30.
Khabour OF, Alzoubi KH, Mfady DS, Alasseiri M and Hasheesh TF (2014). Tempol protects human lymphocytes from genotoxicity induced by cisplatin. Int $\mathrm{J}$ Clin Exp Med. 7(4): 982-988.

Kumazawa S, Taniguchi M, Suzuki Y, Shimura M, Kwon M-S and Nakayama T (2002). Antioxidant activity of polyphenols in carob pods. J Agri Food Chem 50: 373377.

Lee HJ, Jeong HS, Kim DJ, Noh YH, Yuk DYand Hong JT (2008). Inhibitory effect of citral on NO production by suppression of iNOS expression and NFkappa B activation in RAW264.7 cells. Arch of Pharmacol Res 31(3): 342-349.

McClave JT and Dietrich FH (1991). Statistics. Dellen Publishing Company, San Francisc, Fifth Edition: 629.

Meevatee U, Boontim S, Keereeta O, Vinitketkumnuen U and Oariyakul N (1993). Antimutagenic activity of lemon grass, in: Boot-in S. (Ed.), Man and Environment, Chiang Mai University Press p. 346.

Nefic H and Ibrulj S (1999) Citogeneticka analiza genotoksicnog djelovanja cisplatina na humane limfocite in vitro, Med zur 5: 7-12.

Olorunnisola SK, Asiyanbi HT, Hammed AM and Simsek S (2014). Biological properties of lemongrass: An overview. Int Food Res J 21(2): 455-462.

Osanto S, Thijssen JCP, Woldering VMV, Rijn JLS, Natarajan AT and Tates AD (1991). Increased frequency of chromosomal damage in peripheral blood lymphocytes up to nine years following curative chemotherapy of patients with testicular carcinoma. Environ Mol Mutagen 17: 7178.

Perez RP (1998). Cellular and molecular determinants of cisplatin resistance. Euro J Cancer 4 (10): 1535-1542. antibody production and macrophage function in C57BV6N mice. Food and Chem Toxicol 39: 133-139.

Rajewsky MF and Müller R (2002) DNA repair and the cell cycle as targets in cancer therapy. The cancer hand book, $1^{\text {st }}$ edition, 1 . 
Shimoi K, Masuda S, Shen B, Furugori M and Kinae N (1996). Radioprotective effects of antioxidative plant flavonoids in mice. Mut Res 350 (1): 153-161.

Shimoi K, Saka N, Kaji K, Nozawa T and Kinae N (2000) Metabolic fate of luteolin and its functional activity at focal site. Biofactors 12 (14): 181-186.

Souza-Formigoni ML, Lodder HM, Filho OG, Ferreira TM and Carlini EA (1986). Pharmacology of lemongrass (Cymbopogon citratus Stapf). II. Effects of daily two month administration in male and female rats and in offspring exposed "in utero". J Ethnopharmacol 17 (1): 65-74.

Surzychi S (2000). Agarose Gel Electrophoresis of DNA. Basic Techniques in Molecular Biology: 175-178.

Thomas A, Pepper C, Hoy T and Bentley P (2000). Bcl-2 and Bax expression and chlorambucil-induced apoptosis in the T-cells and leukaemic B-cells of untreated B-cell chronic lymphocytic leukaemia patients. Leukemia Res 24 (10): 813-821.
Tiwari M, Dwivedi UN and Kakkar P (2010). Suppression of oxidative stress and pro-inflammatory mediators by Cymbopogon citratus D. Stapf extract in lipopolysaccharide stimulated murine alveolar macrophages. Food Chem Toxicol 48(10): 2913-2919.

Weijl NI, Hopman GD, Wipkink-Bakker A, Lentjes EC, Berger HM, Cleton FJ and Osanto S (1998). Cisplatin combination chemotherapy induces a fall in plasma antioxidants of cancer patients. Ann Oncol 9: 1331-1337.

Yoshida M, Fukuda A, Hara M, Terada A, Kitanaka Y and Owada S (2003). Melatonin prevents the increase in hydroxyl radical-spin trap adduct formation caused by the addition of cisplatin in vitro. Life Sci 72 (15): 1773-1780.

Zhang K, Chew M, Yang EB, Wong KP and Mack P (2001). Modulation of cisplatin cytotoxicity and cisplatininduced DNA cross-links in HepG2 cells by regulation of glutathione-related mechanisms. Mol Pharmacol 59: 837843. 